Jurnal Ekonomi Modernisasi

http://ejournal.unikama.ac.id/index.php/JEKO

JEM 13 (1) 2017, 16-24

\title{
Perilaku Pembelian Konsumen: Sebuah Tinjauan Literatur Theory of Planned Behavior
}

\author{
Meitiana \\ Fakultas Ekonomi dan Bisnis Universitas Palangka Raya
}

\begin{abstract}
This study aims to examine the differences between several empirical articles on the theory of planned behavior. Theory of planned behavior provides a framework for studying attitudes toward behaviors that postulate three determinants of conceptual intent. Specifically, the intention is based on the variables of attitude toward behavior, subjective norms, and perceived behavioral control. Although this theory has been used frequently, there are still differences in outcomes in explaining attitudes toward behavior. The results show that there is still a different view of the theory of planned behavior so it is necessary to identify the gaps that occur in this theory. For further research is expected to expand and enrich the discussion of the theory of planned behavior.
\end{abstract}

Keywords: consumer purchase behavior; theory of planned behavior

\begin{abstract}
Abstrak
Penelitian ini bertujuan menelaah perbedaan beberapa artikel empiris tentang theory of planned behavior. Theory of planned behavior menyediakan suatu kerangka untuk mempelajari sikap terhadap perilaku yang mengemukakan tiga faktor penentu konseptual niat. Secara khusus, niat didasarkan pada variabelvariabel yaitu sikap terhadap perilaku (attitude towards behavior), norma subyektif (subjective norm), dan kontrol berperilaku yang dirasakan (perceived behavioral control). Walaupun teori ini sudah sering digunakan, namun masih terdapat perbedaan hasil dalam menjelaskan sikap terhadap perilaku. Hasil penelitian menunjukkan bahwa masih terdapat perbedaan pandangan terhadap Theory of planned behavior sehingga diperlukan identifikasi kesenjangan yang terjadi dalam teori ini. Penelitian di masa yang akan datang diharapkan dapat memperluas dan memperkaya pembahasan tentang theory of planned behavior.
\end{abstract}

Kata Kunci : perilaku pembelian konsumen; theory of planned behavior

\author{
Permalink/DOI : http://dx.doi.org/10.21067/jem.v13i1.1762 \\ Cara mengutip : Meitiana, M. (2017). Perilaku Pembelian Konsumen: Sebuah Tinjauan Literatur \\ Theory of Planned Behavior. Jurnal Ekonomi Modernisasi, 13(1), 16-24. \\ doi:http://dx.doi.org/10.21067/jem.v13i1.1762
}

Sejarah Artikel $\quad$ : Artikel diterima : Januari 2017; direvisi Februari 2017; diterima Maret 2017

\footnotetext{
Alamat korespondensi :

Fakultas Ekonomi dan Bisnis, Universitas Palangka Raya

Jl. Yos Sudarso Kota Palangka Raya, Kalimantan Tengah

E-mail: meitiana.sahay@gmail.com
} 
Meitiana / Perilaku Pembelian Konsumen ....

\section{Pendahuluan}

Menurut Ajzen dan Fishbein (1980), Theory of Planned Behavior mendalilkan tiga faktor penentu konseptual niat. Secara khusus, niat didasarkan pada variabelvariabel yaitu sikap terhadap perilaku (attitude towards behavior), norma subyektif (subjective norm), dan kontrol berperilaku yang dirasakan (perceived behavioral control). Sikap terhadap perilaku (attitude towards behavior) mengacu pada tingkat evaluasi atau penilaian positif atau negatif individu dari kinerja perilaku. Sikap didasarkan pada keyakinan berperilaku yang menonjol dan evaluasi hasil. Keyakinan berperilaku (behavioral beliefs) mengacu pada kemungkinan yang dirasakan dari terjadinya suatu hasil yang diharapkan karena terlibat dalam perilaku tertentu, dan evaluasi hasil melibatkan penilaian dari kemungkinan konsekuensi dari perilaku tertentu (Han dan Kim, 2010).

Beberapa penelitian terdahulu tentang Theory of Planned Behavior terbukti mampu memprediksi dan menjelaskan perilaku konsumen organik Republik Ceko (Zagata, 2012), dan memahami perilaku belanja konsumen di mal Thailand dan Cina (Cai dan Shannon, 2012), serta menjelaskan perilaku niat yang memiliki dampak positif yang signifikan pada perilaku konsumsi hijau di Taiwan (Wu \& Chen, 2014; Lai dan Cheng, 2015).

Penelitian

Zagata

menyimpulkan bahwa Teori Perilaku yang direncanakan terbukti penerapannya dalam menjelaskan perilaku sosial yang bertujuan untuk pembelian makanan organik. Prediktor terbaik dari niat untuk membeli produk adalah sikap terhadap perilaku dan norma subjektif. Meskipun konteks sejarah yang berbeda di negara-negara pasca-sosialis temuan tersebut menunjukkan bahwa sektor organic Republik Ceko mengikuti pola pengembangan di negara-negara Eropa Barat.

Ketika pembeli lebih utilitarian-driven, model nilai-sikap-niat-perilaku bekerja lebih baik untuk memprediksi perilaku belanja mall konsumen Cina (Cai dan Shannon, 2012). Pada sampel Cina, tugas utama mereka adalah untuk membeli, sehingga setelah mereka menyelesaikan pembelian, mereka lebih cenderung untuk pergi dengan cepat.

Pada konteks produk hijau hasil penelitian Wu dan Chen (2014) menunjukkan bahwa konsumen Taiwan dengan tingkat kesadaran hijau yang lebih tinggi lebih bersedia untuk berlatih konsumsi hijau. Tingkat kesadaran konsumsi hijau yang lebih tinggi berpengaruh lebih besar dengan faktor mediasi sikap, norma subjektif, dan perilaku kontrol terhadap perilaku niat dan perilaku sebenarnya. Niat perilaku dan perilaku kontrol keduanya memiliki dampak positif yang signifikan pada perilaku konsumen yang sebenarnya. Lai dan Cheng (2015) menyimpulkan bahwa persepsi mahasiswa di Hongkong tentang pentingnya praktik pemasaran hijau mempengaruhi sikap mereka terhadap lingkungan, selanjutnya sikap konsumen terhadap lingkungan positif mempengaruhi kesediaan mereka untuk membeli produk hijau, dan akhirnya kesediaan konsumen untuk membeli produk hijau mempengaruhi perilaku pembelian mereka.

Namun penelitian lainnya menunjukkan bahwa niat tidak berpengaruh terhadap perilaku pembelian, seperti hasil penelitian Kothe dan Mullan (2014), Kothe et al. (2012), serta Sanyal (2014). Penelitian Kothe dan Mullan (2014) serta Kothe et al. (2012) menyimpulkan bahwa perubahan niat yang dilaporkan oleh masing-masing peserta 
antara awal dan tindak lanjut tidak berkorelasi dengan perubahan yang sesuai pada konsumsi buah dan sayuran. Bukti saat ini tidak mendukung penggunaan Theory of Planned Behavior dalam desain intervensi untuk meningkatkan asupan buah dan sayuran pada populasi dewasa muda Australia.

Niat tidak selalu memiliki pengaruh positif pada penggunaan aktual dari merekmerek mewah dalam perspektif konsumen India (Sanyal, 2014). Niat untuk membeli tidak selalu menghasilkan pembelian merek mewah, ketika konsumen India berbicara tentang keunikan, eksklusivitas dan selera pribadi, mayoritas pasar masih jauh dari persepsi ini dan nilai merek yang sangat mempengaruhi penggunaan barang mewah. Pola pikir konsumen India masih sebuah 'aspirer' daripada 'ahli karya seni' (Kearney, 2010). Hasil penelitian menunjukkan bahwa di lingkungan pasar India, pelanggan lebih mementingkan norma subyektif daripada sikap mereka sendiri terhadap niat untuk membeli barang-barang mewah. Budaya India kurang lebih budaya kolektif, secara keseluruhan, konsumen kolektivis Asia (India) terlibat dalam pembelian kurang impulsif daripada konsumen individualis Barat, meskipun budaya belanja yang sangat berkembang di Asia.

Beberapa hasil penelitian di atas menunjukkan perbedaan atau "gap" antara sikap konsumen yang menguntungkan dan praktek pembelian aktual. Hubungan yang lemah antara sikap positif konsumen dan perilaku pembelian aktual, umumnya disebut sebagai kesenjangan sikap-perilaku (Vermeir dan Verbeke, 2008). Perbedaan atau kesenjangan antara sikap konsumen yang menguntungkan terhadap perilaku pembelian aktual disebut sebagai "inkonsistensi pembelian" atau "kesenjangan sikap-perilaku" (Joshia dan
Rahman, 2015). Kesenjangan antara sikap dan perilaku tersebut menandakan bahwa sikap positif konsumen terhadap produk tidak selalu diterjemahkan ke dalam tindakan. Hal ini penting untuk memeriksa mengapa sikap memiliki pengaruh yang lebih lemah terhadap perilaku pembelian konsumen.

Theory of Planned Behavior banyak digunakan dalam penelitian perilaku konsumen sebagai pendekatan untuk memprediksi niat dan perilaku, (Simon, 2016). Theory of Planned Behavior mendalilkan tiga faktor penentu konseptual independen dari niat yaitu sikap terhadap perilaku, norma subyektif, dan kontrol perilaku yang dirasakan, dengan kepentingan relatif setiap determinan yang bervariasi di seluruh perilaku dan situasi. Sikap, norma subjektif, dan kontrol perilaku yang dirasakan adalah tiga prediktor langsung niat, yang merupakan prediktor proksimal perilaku (Guo et al., 2016).

Menurut Chen dan Tung (2014) sikap adalah emosi psikologis yang disalurkan melalui evaluasi konsumen, jika positif, niat berperilaku cenderung lebih positif (Paul et al, 2016). Menurut Ajzen (1991) sikap terhadap perilaku ditentukan oleh kombinasi antara keyakinan individu mengenai konsekuensi positif dan atau negatif dari melakukan suatu perilaku dengan nilai subyektif individu terhadap setiap konsekuensi berperilaku tersebut (Lee, 2016).

Model dalam Theory of Planned Behavior menunjukkan bahwa niat adalah anteseden langsung dari perilaku (Simon, 2016). Niat berperilaku menandakan rencana dan tekad untuk melakukan perilaku yang ditargetkan. Secara umum, niat individu untuk melakukan perilaku tertentu tumbuh lebih kuat sesuai dengan sikap positif yang dimiliki tentang perilaku. Semakin kuat niat 
seseorang untuk melakukan perilaku, semakin besar kemungkinan perilaku yang akan dilakukan (Ajzen, 1991). Pemahaman terhadap niat beli konsumen sangat penting karena perilaku pembelian terakhir mereka dapat diprediksi dari niat mereka. Konsumen memutuskan apakah mereka berniat untuk melanjutkan dengan pembelian berdasarkan informasi yang tersedia bagi mereka (Pappas, 2016). Niat telah digunakan sebagai langkah alternatif untuk perilaku membeli, sehingga diharapkan bahwa sikap wisatawan yang menguntungkan terhadap souvenir akan memprediksi niat mereka untuk membeli souvenir.

Perilaku konsumen mencerminkan suka dan tidak suka konsumen terhadap suatu produk (Kotler dan Keller, 2012). Shail dan Antoine (2004) merekomendasikan bahwa pemasar harus memahami perilaku konsumen sehingga dapat menciptakan produk dan jasa yang menjanjikan kepuasan maksimal. Pemahaman terhadap perilaku konsumen dapat membantu untuk memahami faktorfaktor yang berhubungan dengan ilmu-ilmu sosial yang mempengaruhi perilaku manusia (Parsa et al. 2016). Pengetahuan tentang perilaku konsumen membantu pemasar untuk memahami bagaimana konsumen berpikir, merasa dan memilih dari alternatif seperti produk, merek dan sejenisnya dan bagaimana konsumen dipengaruhi oleh lingkungan mereka, kelompok referensi, keluarga, dan tenaga penjualan dan sebagainya. Perilaku pembelian konsumen dipengaruhi oleh faktor budaya, sosial, pribadi dan psikologis. Sebagian besar faktor perilaku pembelian tersebut tidak dapat dikendalikan oleh pemasar tetapi faktorfaktor tersebut harus dipertimbangkan ketika mencoba untuk memahami perilaku kompleks dari konsumen (Brosekhan dan Velayutham, 2013).
Penelitian yang dilakukan oleh Zagata (2012) tentang keyakinan yang mempengaruhi keputusan dan perilaku konsumen Republik Ceko terhadap makanan organik menyimpulkan bahwa Teori Perilaku yang direncanakan terbukti penerapannya dalam memprediksi dan menjelaskan perilaku sosial yang bertujuan untuk pembelian makanan organik. Model diuji pada sampel yang representatif besar yaitu $\mathrm{N}=1054$ dari konsumen dan kemampuan prediksi yang sesuai dengan contoh-contoh lainnya. Hasil penelitian menegaskan bahwa adalah mungkin untuk memprediksi perilaku konsumen organik dengan niat untuk membeli makanan organik, yang dapat dijelaskan lebih lanjut oleh sikap, norma subjektif dan kontrol perilaku yang dirasakan dengan menggunakan model TPB standar. Niat untuk membeli makanan organik dalam konteks Republik Ceko ditentukan terutama oleh sikap positif konsumen terhadap makanan organik. Prediktor terbaik dari niat untuk membeli makanan organik adalah sikap terhadap perilaku dan norma subjektif. Meskipun konteks sejarah yang berbeda di negara-negara pasca-sosialis temuan menunjukkan bahwa sektor organik Republik Ceko mengikuti pola pengembangan di negara-negara Eropa Barat. Hal ini berarti bahwa promosi dan dukungan praktis untuk sektor organik harus fokus pada penguatan sikap positif terhadap pembelian organic sehingga sangat mungkin kesediaan konsumen untuk membayar produk organik yang berkualitas premium meningkat.

Penelitian Wu dan Chen (2014) menyimpulkan bahwa sikap secara signifikan berhubungan positif dengan niat perilaku. Selanjutnya niat perilaku secara signifikan berhubungan positif dengan perilaku aktual. Hasil penelitian menunjukkan bahwa konsumen Taiwan 
dengan tingkat kesadaran hijau yang lebih tinggi lebih bersedia untuk berlatih konsumsi hijau. Oleh karena itu, tingkat kesadaran hijau yang lebih tinggi berpengaruh lebih besar dengan faktor mediasi sikap, norma subjektif, dan perilaku kontrol terhadap perilaku niat dan perilaku sebenarnya. Perilaku niat dan perilaku kontrol keduanya memiliki dampak positif yang signifikan pada perilaku konsumen yang sebenarnya. Hasil penelitian memberikan referensi kepada manajer industri dalam perumusan strategi pemasaran hijau.

Penelitian Lai dan Cheng (2015) bertujuan untuk menguji pengaruh persepsi praktik pemasaran hijau mahasiswa di Hongkong pada sikap mereka terhadap lingkungan, anggapan mereka tentang masalah keseriusan lingkungan, dan tanggung jawab lingkungan mereka. Selain itu, mengkaji apakah niat membeli mereka berpengaruh terhadap perilaku produk hijau. Penelitian tersebut mencerminkan tentang harapan mahasiswa dari praktek pemasaran hijau, persepsi lingkungan, dan perilaku pembelian, dan memberikan wawasan bagi pemasar hijau untuk merumuskan strategi yang dapat mendorong mahasiswa untuk mengkonsumsi produk hijau. Hasil penelitian menunjukkan bahwa praktik pemasaran hijau harus terus menerus untuk dipromosikan di Hong Kong, khususnya aspek eco-labeling dan cara-cara komunikasi yang ramah lingkungan, untuk meningkatkan pengetahuan konsumen tentang konsep tersebut.

Penelitian Chai dan Shannon (2012) tentang perilaku belanja konsumen di mal Thailand dan China menyimpulkan bahwa pembeli Thailand lebih hedonic-driven, sedangkan perilaku belanja mal konsumen Cina lebih utilitarian-driven. Konsumen Thailand yang memiliki sikap yang menguntungkan terhadap atribut mal lebih cenderung menghabiskan lebih banyak uang dan waktu di mall. Namun, sikap yang menguntungkan tidak menyebabkan frekuensi belanja yang lebih tinggi. Salah satu alasan yang mungkin bahwa mayoritas responden Thailand relatif lebih tua dari responden Cina karena mereka mungkin memiliki pekerjaan, sehingga memiliki sedikit waktu yang tersedia, namun karena didorong oleh kebutuhan hedonis, mereka dapat memilih untuk mengunjungi mall kurang sering tetapi tetap relatif lebih lama. Niat belanja tidak mempengaruhi perilaku belanja mereka secara signifikan, mengingat bahwa tujuan utama mereka adalah untuk bersantai dan bersenang-senang di mall. Pada sampel Cina, tugas utama mereka adalah untuk membeli, sehingga setelah mereka menyelesaikan pembelian, mereka lebih cenderung untuk pergi dengan cepat. Mayoritas responden Cina relatif muda yang mungkin memiliki sedikit kendala waktu, atau mereka mungkin mencoba untuk meminimalkan pengeluaran di setiap perjalanan yang diberikan.

Hasil studi Kothe et al. (2012) yang mengevaluasi efektivitas dari Theory of Planned Behavior (TPB) berdasarkan intervensi untuk meningkatkan konsumsi buah dan sayuran pada konsumen dewasa muda Australia, menyimpulkan bahwa perubahan perilaku tidak diprediksi oleh perubahan niat. sehingga dikatakan bahwa model TPB kurang baik bila digunakan untuk memprediksi perilaku. Studi lanjutan yang dilakukan oleh Kothe dan Mullan (2014) berusaha untuk mengevaluasi kembali dengan menggunakan uji coba terkontrol secara acak. Namun, niat dan konsumsi buah dan sayur tidak berubah sebagai hasil dari intervensi. Perubahan niat yang dilaporkan oleh masing-masing peserta antara awal dan tindak lanjut tidak 


\section{Meitiana / Perilaku Pembelian Konsumen ....}

berkorelasi dengan perubahan yang sesuai pada konsumsi buah dan sayuran. Bukti saat itu tidak mendukung penggunaan Theory of Planned Behavior dalam desain intervensi untuk meningkatkan asupan buah dan sayuran pada populasi dewasa muda Australia.

Sanyal (2014) meneliti sikap konsumen tentang barang mewah dalam perspektif konsumen India. Niat tidak selalu memiliki pengaruh positif pada penggunaan aktual dari merek-merek barang mewah. Ketika konsumen India berbicara tentang keunikan, eksklusivitas dan selera pribadi, mayoritas pasar masih jauh jauh dari persepsi ini dan nilai merek yang sangat mempengaruhi penggunaan barang mewah. Hasil penelitian membuktikan bahwa di lingkungan pasar India, pelanggan lebih mengutamakan norma subyektif daripada sikap mereka sendiri sementara mereka memiliki niat untuk membeli barang-barang mewah. Budaya India kurang lebih budaya kolektif, secara keseluruhan, konsumen kolektivis Asia (India) terlibat dalam pembelian kurang impulsif daripada konsumen individualis Barat, meskipun budaya belanja yang sangat berkembang di Asia.

\section{Pembahasan}

Beberapa penelitian tentang Theory of Planned Behavior telah berhasil digunakan untuk memprediksi niat. Niat merupakan anteseden langsung dari perilaku, artinya semakin kuat niat seseorang untuk melakukan perilaku, semakin besar kemungkinan perilaku tersebut akan dilakukan (Ajzen, 1991). Walaupun perilaku pembelian terakhir dapat diprediksi dari niat, namun tidak selalu bahwa niat akan menghasilkan perilaku pembelian.
Theory of Planned Behavior menurut Padel dan Foster (2005) tidak dianggap sebagai model yang cocok untuk menjelaskan perilaku dalam kebanyakan studi karena tidak mempertimbangkan unsur afektif konsumen yang ditemukan untuk mempengaruhi perilaku konsumen (Joshi dan Rahman, 2015). Theory of Planned Behavior hanya berfokus pada aspek kognitif dari sikap (yaitu, sikap kognitif), sehingga menunjukkan bahwa konsep sikap harus diperiksa melalui baik sikap kognitif dan sikap afektif, yaitu perasaan atau emosi (Taut dan Baban, 2012). Hasil penelitian menunjukkan bahwa model tersebut tidak bisa digunakan untuk memprediksi perilaku, sehingga niat pembelian tidak berpengaruh terhadap perilaku pembelian, seperti hasil penelitian Kothe dan Mullan (2014), Kothe et al. (2012), Cai dan Shannon (2012), serta Sanyal (2014).

Perbedaan hasil penelitian tersebut disebabkan karena lokasi penelitian yang mempunyai budaya yang berbeda, penelitian Sanyal (2014) pada lingkungan pasar dan budaya India menunjukkan budaya kolektif dimana konsumen kolektivis kurang impulsif bila dibandingkan konsumen individualis barat, meskipun budaya belanja yang sangat berkembang di Asia termasuk India. Konsumen India lebih mementingkan norma subyektif daripada sikap mereka sendiri ketika memiliki niat untuk membeli suatu produk.

Temuan Sanyal (2014) mendukung dan memperluas penelitian sebelumnya yang menemukan bahwa pelanggan dengan budaya kolektif mampu mempertahankan hubungan sikap-perilaku yang tidak konsisten dan menempatkan perasaan mereka sendiri untuk bertindak dengan cara yang tepat. Meskipun kolektivis memiliki sifat membeli impulsif dalam ukuran yang sama dengan individualis, mereka menekan 
sifat impuls dan bertindak dengan cara yang konsisten berdasarkan norma-norma budaya.

Perbedaan hasil penelitian lainnya terdapat pada penelitian Kothe et al. (2012), dimana model Theory of Planned Behavior tidak bisa digunakan untuk memprediksi perilaku. Kurangnya dukungan terhadap model Theory of Planned Behavior disebabkan beberapa kemungkinan, pertama yaitu bahwa intervensi ternyata tidak efektif untuk menyebabkan perubahan konsumsi buah dan sayuran; yang kedua adalah bahwa perubahan niat tidak terkait dengan perubahan perilaku. Tidak efektifnya intervensi disebabkan karena bahan intervensi menggunakan sarana email yang dikirimkan kepada perserta. Hal tersebut dianggap kurang efektif bila dibandingkan dengan intervensi misalnya membawa langsung buah dan sayuran kepada peserta.

Theory of Planned Behavior telah berulang dikritik karena pertimbangan tidak cukupnya konstruksi perilaku manusia lainnya (Arvola et al. 2008). Theory of Planned Behavior juga tidak dianggap sebagai model yang cocok untuk menjelaskan perilaku dalam kebanyakan studi karena tidak mempertimbangkan unsur afektif konsumen yang ditemukan untuk mempengaruhi perilaku konsumen (Padel dan Foster, 2005 dalam Joshi dan Rahman, 2015). Theory of Planned Behavior hanya berfokus pada aspek kognitif dari sikap (yaitu, sikap kognitif), sehingga menunjukkan bahwa konsep sikap harus diperiksa melalui baik sikap kognitif dan sikap afektif, yaitu perasaan atau emosi (Taut dan Baban, 2012).

Walaupun beberapa penelitian menunjukkan bahwa model Theory of Planned Behavior kurang baik digunakan untuk memprediksi perubahan perilaku namun sejumlah besar studi lainnya memberikan dukungan untuk utilitas model dalam memprediksi perilaku. Theory of Planned Behavior adalah yang paling sangat mendukung model niat dan perilaku (Guillaumie et al. 2010). Theory of Planned Behavior dikatakan adalah contoh yang paling umum diterapkan, model Theory of Planned Behavior merupakan model yang parsimoni dan sukses dalam memprediksi perilaku pada umumnya (Watson et al, 2014.) dan juga menyelidiki hubungan antara sikap dan tindakan (Webb dan Sheeran, 2006).

Meskipun keberhasilan Theory of Planned Behavior dalam hal memprediksi perilaku telah terbukti, teori tidak berhenti berkembang, dan ilmuwan lain di berbagai domain penelitian telah menyatakan keyakinan bahwa untuk beberapa perilaku dan konteks, dimasukkannya variabel lain dapat meningkatkan utilitas prediksi model. Ajzen (1991) berpendapat bahwa model itu "pada prinsipnya, terbuka untuk masuknya prediktor tambahan jika dapat menunjukkan bahwa mereka menangkap proporsi yang signifikan dari variasi dalam niat atau perilaku" (Yazdanpanah \& Forouzani, 2015). Hal ini penting untuk dicatat, bahwa masuknya variabel-variabel ini, sementara tidak diperlukan dalam semua kasus, adalah penting dalam situasi tertentu (Burton, 2004).

\section{Simpulan}

Theory of Planned Behavior merupakan teori yang awalnya digunakan pada kajian psikologi sosial, namun teori ini juga digunakan pada bidang-bidang lain seperti kesehatan dan olahraga, pendidikan, pemasaran, perilaku organisasi, dan bidang lainnya. Walaupun Theory of Planned Behavior sudah banyak digunakan dalam beberapa penelitian, namun penelitian-penelitian tersebut menemukan hasil yang berbeda. Teori ini dalam beberapa penelitian tidak 
dianggap sebagai model yang cocok dan kurang baik digunakan untuk menjelaskan dan memprediksi perilaku.

Terdapatnya kesenjangan antara sikap terhadap perilaku pembelian aktual, membuka peluang bagi penelitian selanjutnya untuk mempertimbangkan perlunya memasukkan variabel lain agar dapat meningkatkan dan memberikan dukungan untuk utilitas model dalam memprediksi perilaku.

\section{Daftar Pustaka}

Ajzen, I., \& Fishbein, M. (1980). Understanding attitudes and predicting social behavior. Englewood-Cliffs, NJ: Prentice-Hall.

Ajzen, I. (1991). The Theory of Planned Behavior. Organizational Behavior and Human Decision Processes 50: 179-211.

Arvola, A.M., Vassallo, M., Dean, P., Lampila, A., Lahteenmaki, S.A., Shepherd, R., (2008). Predicting intentions to purchase organic food: the role of affective and moral attitudes in the Theory of Planned Behaviour. Appetite 50: 443-454.

Brosekhan, A.A., and Velayutham, C.M. (2013). Consumer Buying Behaviour - A Literature Review. IOSR Journal of Business and Management (IOSR-JBM) e-ISSN : 2278-487X, p-ISSN : 2319-7668, PP 08-16.

Burton, R., (2004). Reconceptualising the 'behavioural approach' in agricultural studies: a sociopsychological perspective. Journal of Rural Study. 20 (3), 359-371.

Cai, Y., and Shannon, R. (2012). Personal Values and Mall Shopping Behavior: The Mediating Role of Attitude and Intention Among Chinese and Thai Consumers. Australasian Marketing Journal 20: 37-47.

Chen, M.F., and Tung,P.J. (2014). Developing an extended Theory of
Planned Behaviour model to predict consumers' intention to visit green hotels. International Journal Hospitality Management 36: 221-230.

Guillaumie, L., Godin, G., \& Vezina-Im, LA. (2010). Psychosocial determinants of fruit and vegetable intake in adult population: a systematic review. International Journal Behavior Nutrition Psychology Act. 2;7:12.

Guo, J.L., Wang, T.F., Liao, J.Y., and Huang, C.M. (2016). Efficacy of the Theory of Planned Behavior in predicting breastfeeding: Metaanalysis and structural equation modeling. Applied Nursing Research 29: 37-42.

Han, H., Kim, Y. (2010). An investigation of green hotel customers' decision formation: Developing an extended model of the Theory of Planned Behavior. International Journal of Hospitality Management 29: 659-668

Joshia, Y., and Rahman, Z. (2015). Factors Affecting Green Purchase Behaviour and Future Research Directions. International Strategic Management Review 3: 128-143.

Kearney, A.T. (2010). Luxury in India: charming the snakes and scaling the ladders, Market Report, SeptemberOctober, pp.78-90.

Kothe, E.J. and Mullan, B.A. (2014). A randomised controlled trial of a theory of planned behaviour to increase fruit and vegetable consumption. Fresh Facts. Appetite 78C: $68-75$.

Kothe, E.J., Mullan, B.A., and Butow, P. (2012). Promoting fruit and vegetable consumption. Testing an intervention based on the Theory of Planned Behavior. Appetite 58: 9971004.

Kotler, P. and Keller KL. (2012). Marketing Management, $14^{\text {th }}$ ed. New Jersey: Pearson Prentice Hall, Inc. 
Lai, C.K.M., and Cheng, E.W.L. (2015). Green purchase behavior of undergraduate students in Hong Kong. The Social Science Journal xxx $\mathrm{xxx}-\mathrm{xxx}$.

Lee, H. (2016). Examining neighborhood influences on leisure-time walking in older Korean adults using an extended Theory of Planned Behavior. Landscape and Urban Planning 148: 51-60.

Padel, S., \& Foster, C. (2005). Exploring the gap between attitudes and behaviour: Understanding why consumers buy or do not buy organic food. British food joumal, 107(8), 606-625.

Pappas, N. (2016). Marketing strategies, perceived risks, and consumer trust in online buying behavior. Journal of Retailing and Consumer Services 29: 92103.

Parsa, A., Nooraieb, M., and Aghamohamadia, A. (2016). A Comparison between Dairy Consumer Behavior of the Islamic Republic of Iran and France (with Cultural Approach). Procedia Economics and Finance 36: 157 - 164

Paul, J., Modi, A., and Patel, J. (2016). Predicting green product consumption using Theory of Planned Behavior and reasoned action. Journal of Retailing and Consumer Services 29: 123-134

Sanyal, S.N. (2014). Attitude of Indian consumers towards luxury brand purchase: an application of 'attitude scale to luxury items. International Journal Indian Culture and Business Management, Vol. 9, No. 3.

Shail, P. and Antoine, S. (2004). "Models of consumer behaviour problem", available at: www.smithinst.ac.uk/Projects/ESG I49/ESGI49unilever Consumers/index_html (accessed 12 September 2012).
Simon, F. (2016). Consumer adoption of No Junk Mail stickers: An extended planned behavior model assessing the respective role of store flyer attachment and perceived intrusiveness. Journal of Retailing and Consumer Services 29: 12-21.

Taut, D., Baban, A., (2012). Relative contribution of affective and cognitive attitudes in predicting physical activity. Cognitive Brain Behavior Interdisciplin Journal. 16,403421.

Vermeir, I., \& Verbeke, W. (2008). Sustainable food consumption among young adults in Belgium: Theory of planned behaviour and the role of confidence and values. Ecological Economics, 64(3), 542-553.

Watson, M.C., Johnston, M., Entwistle, V., Lee, A.J., Bond, C.M., Fielding, S., (2014). Using the theory of planned behaviour to develop targets for interventions to enhance patient communication during pharmacy consultations for non-prescription medicines. International Journal Pharmacy Practice. 26 (6), 386-396.

Webb, T.L., Sheeran, P. (2006). Does changing behavioral intentions engender behavior change? A metaanalysis of the experimental evidence. Psychological Bulletin. 132 (2), 249.

Wu, S. and Chen, J. (2014). A Model of Green Consumption Behavior Constructed by the Theory of Planned Behavior. International Journal of Marketing Studies; Vol. 6, No. 5.

Yazdanpanah, M., \& Forouzani, M. (2015). Application of the Theory of Planned Behaviour to predict Iranian students' intention to purchase organic food. Journal of Cleaner Production 107: 342-352.

Zagata, L. (2012). Consumers' beliefs and behavioural intentions towards organic food. Evidence from the Czech Republic. Appetite 59: 81-89. 